\title{
Assistive technologies for managing language disorders in dementia
}

\author{
This article was published in the following Dove Press journal: \\ Neuropsychiatric Disease and Treatment \\ 29 February 2016 \\ Number of times this article has been viewed
}

\author{
Blanka Klimova' \\ Petra Maresova ${ }^{2}$ \\ Kamil Kuca ${ }^{3,4}$ \\ 'Department of Applied Linguistics, \\ ${ }^{2}$ Department of Economics, Faculty \\ of Informatics and Management, \\ University of Hradec Kralove, \\ ${ }^{3}$ Biomedical Research Centre, \\ University Hospital Hradec Kralove, \\ ${ }^{4}$ Center for Basic and Applied \\ Research, Faculty of Informatics and \\ Management, University of Hradec \\ Kralove, Hradec Kralove, Czech \\ Republic
}

\begin{abstract}
At present, the number of elderly people is rapidly increasing, which represents a significant threat in terms of their care when they fall ill. One of the most common aging diseases nowadays is dementia, whose symptoms sooner or later include loss of cognitive functioning. Cognitive disorders can vary from serious mental retardation to inability to recall things, to the loss or disorder of specific cognitive functions such as communication. These disorders not only affect the quality of people's own life but also impose a substantial burden on their families, particularly on their caregivers. Therefore, the aim of this article is to highlight the role of assistive technologies (ATs) for managing language impairments in dementia in order to improve patients' quality of life. In addition, ATs focused on training patients' memory are also mentioned, since they can help patients to maintain their language skills. Furthermore, these ATs can delay the need for institutional care, as well as significantly reduce costs on patient care. The importance of future research in the area of the development of ATs for managing the language impairments in dementia is also discussed. There is a general trend toward the personalization of patient needs and requirements in the area of ATs. For the purpose of this article, a method of literature review of available sources defining language disorders and providing characteristic features of language disorders in dementia is used. In addition, a method of comparison of different research studies exploring ATs focused on delaying language disorders in dementia in order to postpone patients' need for institutional care is also exploited.
\end{abstract}

Keywords: assistive technologies, dementia, language impairments, improvement

\section{Introduction}

One of the most common aging diseases is dementia. ${ }^{1}$ Demographic changes of the world's population and an expected increase in the occurrence of age-related diseases, including dementia, are a subject of special interest. Dementia affects $\sim 5.4 \%$ of people aged 65 years and above, and its prevalence increases with age. At present, there are $\sim 47.5$ million people suffering from dementia worldwide, and the number has been increasing by 7.7 million every year. It is estimated that $57.7 \%$ of these people with dementia were located in developing countries in 2010. And it is expected that by 2030, the total number will have risen to $70.5 \%$ and by 2050 it will have increased by three times, to 135.5 million. ${ }^{2}$

Dementia is one of the main reasons for incapacity and dependency of elderly people all over the world. It is one of the brain diseases that cause a significant decline in mental performance. It usually starts with a gradual loss of memory, attention, and reasoning abilities. There are different reasons behind this process such as an impediment to blood flow into the brain, stroke, malnutrition, or trauma. The most common types of dementia are as follows: Alzheimer's disease (AD), vascular dementia, dementia with Lewy bodies, mixed dementia, Parkinson's disease, frontotemporal lobar degeneration, Creutzfeldt-Jakob disease, and normal pressure hydrocephalus. ${ }^{1}$
Correspondence: Kamil Kuca

Biomedical Research Centre, University Hospital Hradec Kralove, Sokolska 58I, Hradec Kralove 500 05, Czech Republic Tel +420603289166

Fax +420495835200

Email kamil.kuca@fnhk.cz
Neuropsychiatric Disease and Treatment 2016:12 533-540

533

Dovepress

http://dx.doi.org/10.21 477/NDT.S95903 (c) (1) (5) 2016 Klimova et al. This work is published and licensed by Dove Medical Press limited. The full terms of this license are available at https://www.dovepress.com/terms.php (c) ${ }_{\mathrm{BY}} \mathrm{NC}$ and incorporate the Creative Commons Attribution - Non Commercial (unported, v3.0) License (http://creativecommons.org/licenses/by-nc/3.0/). By accessing the work you hereby accept the Terms. Non-commercial uses of the work are permitted without any further permission from Dove Medical Press Limited, provided the work is properly attributed. For permission for commercial use of this work, please see paragraphs 4.2 and 5 of our Terms (https://www.dovepress.com/terms.php). 
Dementia is not just a particular disease with one cause, it is a syndrome. More specifically, it is an accumulation of symptoms, especially disorders in cognitive functions, including language, that together cause problems in daily functioning. ${ }^{3}$ Cognitive disorders can vary from serious mental retardation to inability to recall things, to the loss or disorder of specific cognitive functions, especially language. These cognitive impairments can be categorized as follows: ${ }^{4}$ memory, perception, problem-solving, conceptual, and language disorders. Memory disorders involve problems with obtaining information from short-term, long-term, and remote memory. This causes difficulties in recognizing and retrieving information. Perception disorders consist of difficulties with sensory information. Problem-solving disorders are connected with difficulties in identifying problems, generating solutions, and evaluating the effectiveness of the solutions. Conceptual disorders cause difficulties in generalizing the obtained information, its structuring, abstracting, or comprehending. Language disorders in dementia include difficulties in understanding and correct phrasing of spoken and written utterances. The causes of speech and language disorders can include hearing loss, neurological disorders, brain injury, intellectual disabilities, drug abuse, physical disorders (eg, cleft lip or palate), and vocal abuse or misuse. However, very often, the cause of language disorders is not known. At present, there are a few assistive technologies (ATs) for people with dementia such as speech-generating devices (SGDs), which can help enhance patients' verbal communication, and memory aids, which can help patients to recall names. All these assistive devices are described in length in the "ATs and language disorders" section.

The goal of this article is to highlight the role of ATs for managing language disorders in dementia in order to improve patients' quality of life. The focus is mainly placed on the use of ATs for language impairments in $\mathrm{AD}$ and frontotemporal lobar degeneration since they encompass the most common language disorders including nonfluent aphasia and semantic aphasia. In addition, ATs focused on training patients' memory are also mentioned since they can help patients to maintain their language skills.

\section{Methods}

\section{Methodological approaches}

Traditional research methods are employed. First, a literature review of available sources defining language disorders and providing characteristic features of language disorders in dementia is used. Second, a method of comparison of different research studies exploring ATs focused on assisting people with their language disorders in dementia in order to postpone patients' need for institutional care is also exploited. Research studies were selected through searching for peer-reviewed articles in the Web of Science in the period 1945-2015. These research studies were classified according to their relevancy. The keywords were as follows:

- "Assistive technologies AND dementia" (the number of results was 190)

- "Assistive technologies AND language impairments" (the number of results was 48)

- "Assistive technologies AND language disorders" (the number of results was 28).

The selection of the final set of studies involved the following four steps:

- identification of keywords and consequently available relevant sources

- duplication check

- assessment of relevancy (verification on the basis of abstracts whether the selected study corresponds to the set goal; after the exclusion of studies that did not meet the criteria, 131 sources were analyzed and 88 eventually excluded)

- use of available studies.

The duplication of articles was mainly found in the databases of Scopus and Web of Science when compared with other freely accessible sources. After the close exploration of the abstracts, articles that contained the keywords but whose findings were not aimed at the set goal were excluded. In addition, studies outside the time span, those that comprised the same findings, and those whose findings were outdated were also excluded (Figure 1).

As can be seen from the results presented in Figure 1, there are not many studies on ATs for managing language impairments in dementia. Moreover, research studies on ATs and dementia mainly deal with health care or telecare. The studies on ATs and language impairments/disorders focus on hearing and visual impairments, and if there is a study on language impairments, it is connected with mild or moderate dementia.

\section{Language disorders and their characteristics in different types of dementia}

Generally, a language disorder can be defined as an impaired language system, involving word finding, word retrieval, or anomia. ${ }^{5}$ These language disorders result in inappropriate use of words and their meanings, inability to express 


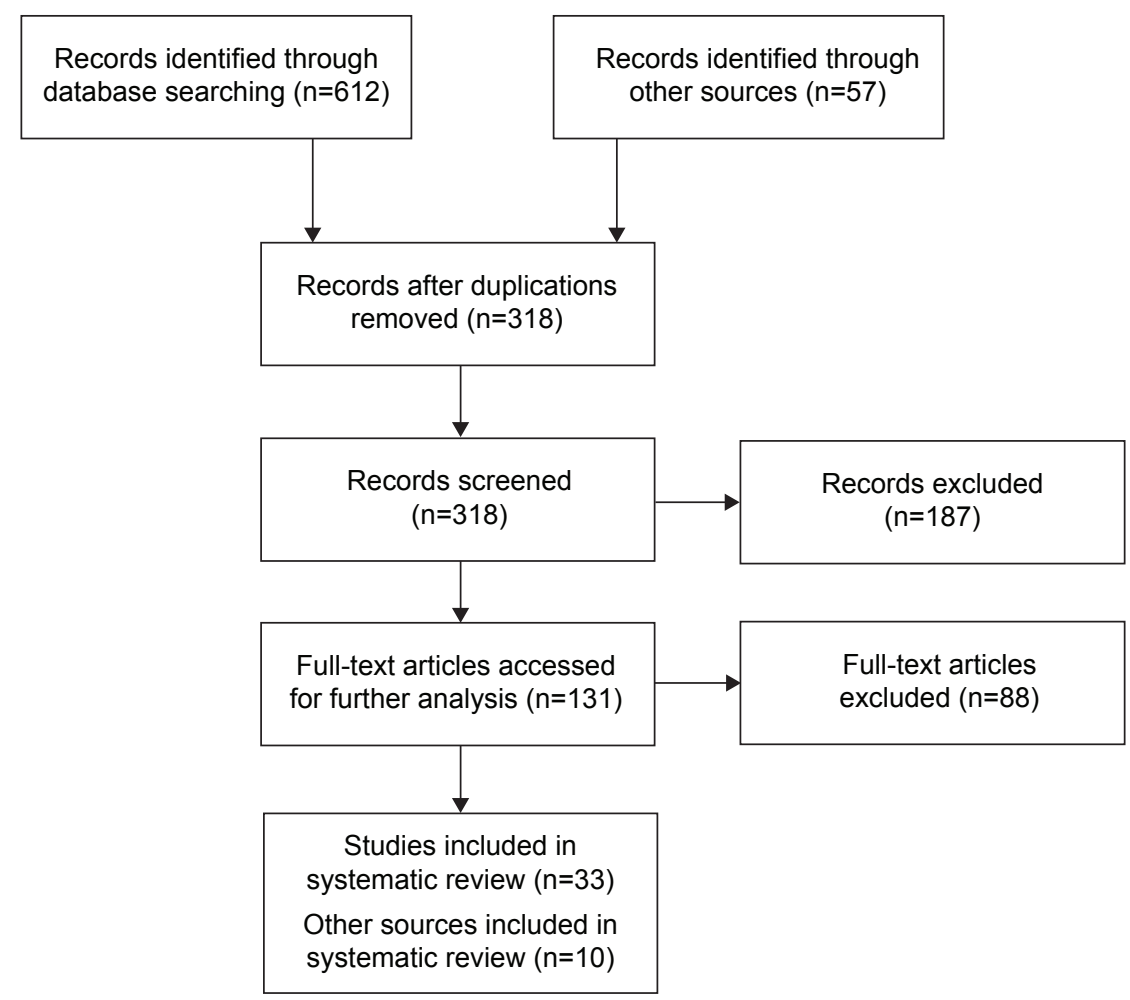

Figure I Results of the systematic review.

one's ideas, wrong use of grammatical word forms, limited vocabulary, nonfluent speech, or talking too fast or too slow. ${ }^{6}$ More specifically, language impairments include the form of language, which consists of the sound system of a language (phonology), the system that deals with the correct formation of word forms (morphology), and the system that is responsible for making the correct sentences and the relationships between the sentence units (syntax), the content of language, its meaning (semantics), and the role of language in social interactions (pragmatics).

Although language disorders are common among young children, ${ }^{7}$ they also affect the aging population. Therefore, this article focuses mainly on language disorders in dementia, and particularly in AD and frontotemporal lobar degeneration, since they encompass the most common language disorders including nonfluent aphasia or semantic aphasia.

In the early period of $\mathrm{AD}$, the language system and its comprehension is only slightly impaired, particularly in the areas of identifying and comprehending less known words, while the other areas of language such as communication, repetition, and understanding of the meaning of individual words or whole sentences are intact. However, in the second (mild) and third (severe) periods, most of the language is impaired. ${ }^{8,9}$
Frontotemporal dementia is a less common form of dementia, but besides behavioral and emotional changes, it is connected with severe difficulties in language. People thus suffer from progressive nonfluent aphasia, which manifests itself in slow speaking, grammatically incorrect words, or impaired understanding of complex sentences. Patients can also have semantic aphasia. In this case, speech is fluent but patients have problems with finding words and understanding what the object is. ${ }^{10}$

\section{ATs and language disorders}

From the review study point of view, altogether 131 studies were researched. They are the most current comprehensive studies. The studies that focused on the selected types of technologies were 34 and those that aimed at the testing of technologies for given disorders were nine. The list of studies and their major findings are presented in Table 1.

AT devices and services were first defined in federal law in the Individuals with Disabilities Education Act of 1990 (Public Law 101-476). These definitions remained unchanged until 2004 with the passage of the Individuals with Disabilities Education Improvement Act (Public Law 108-446) when an exemption to the definition of an AT device was added to clarify a school system's responsibility to provide surgically 
Table I List of studies and their main findings

\begin{tabular}{|c|c|c|c|c|}
\hline Author(s) & Name of the study & Goal & Main results & Type of the study \\
\hline Bharucha et $\mathrm{al}^{23}$ & $\begin{array}{l}\text { Intelligent assistive } \\
\text { technology applications } \\
\text { to dementia care: current } \\
\text { capabilities, limitations, } \\
\text { and future challenges }\end{array}$ & $\begin{array}{l}\text { To conduct a review of intelligent } \\
\text { cognitive technologies, } \\
\text { physiologic and environmental } \\
\text { sensors, and advanced integrated } \\
\text { sensor networks that might be } \\
\text { applied in dementia care }\end{array}$ & $\begin{array}{l}\text { Assistive technologies (ATs) for } \\
\text { cognitive impairments focused mainly } \\
\text { on the development of memory } \\
\text { aids. So far, there have been only } \\
\text { six devices for progressive cognitive } \\
\text { decline. A certain level of success } \\
\text { was confirmed in its early stages }\end{array}$ & Review study \\
\hline LoPresti et al ${ }^{24}$ & $\begin{array}{l}\text { Assistive technology for } \\
\text { cognitive rehabilitation: } \\
\text { state of the art }\end{array}$ & $\begin{array}{l}\text { To perform a thorough literature } \\
\text { review in the area of ATs for } \\
\text { cognition }\end{array}$ & $\begin{array}{l}\text { ATs focused on cognitive disorders } \\
\text { can be divided into two types: ATs } \\
\text { for cognition and for augmentative } \\
\text { and alternative communication } \\
\text { (AAC) }\end{array}$ & \\
\hline $\begin{array}{l}\text { DeVaul }{ }^{25} \\
\text { Pollack et } \mathrm{al}^{26}\end{array}$ & $\begin{array}{l}\text { The Memory Glasses } \\
\text { Project } \\
\text { Autominder: an intelligent } \\
\text { cognitive orthotic system } \\
\text { for people with memory } \\
\text { impairment }\end{array}$ & $\begin{array}{l}\text { To determine the possibilities of } \\
\text { using specific technologies for the } \\
\text { improvement in cognition. The } \\
\text { studies describe the following } \\
\text { devices: prospective memory aids } \\
\text { (PMAs) and retrospective memory } \\
\text { aids (RMAs) }\end{array}$ & $\begin{array}{l}\text { Chosen kinds of technological } \\
\text { devices could enormously contribute } \\
\text { to recalling people's names and } \\
\text { recognizing them in an easy manner }\end{array}$ & $\begin{array}{l}\text { Specification } \\
\text { and use of the } \\
\text { selected types } \\
\text { of technologies }\end{array}$ \\
\hline $\begin{array}{l}\text { Fried-Oken }{ }^{27} \\
\text { Aetna } \operatorname{lnc}^{28} \\
\text { Blischak et } \mathrm{al}^{29}\end{array}$ & $\begin{array}{l}\text { Communication supports } \\
\text { for persons with } \\
\text { dementia } \\
\text { Speech-generating } \\
\text { devices } \\
\text { Use of speech-generating } \\
\text { devices: in support of } \\
\text { natural speech }\end{array}$ & $\begin{array}{l}\text { To provide the specifications of } \\
\text { the selected technologies for the } \\
\text { support of language disorders, } \\
\text { possible guidelines, and possibilities } \\
\text { of their use }\end{array}$ & $\begin{array}{l}\text { AAC refers to any strategy, } \\
\text { technique, or tool that enhances, } \\
\text { replaces, augments, or supplements } \\
\text { an individual's capabilities. These } \\
\text { include external memory aids such } \\
\text { as notebooks, cards, or timers, } \\
\text { especially speech-generating devices } \\
\text { and computers that act as people's } \\
\text { schedules or reminders }\end{array}$ & \\
\hline Turner et $\mathrm{al}^{20}$ & $\begin{array}{l}\text { Rigorous development } \\
\text { of prompting dialogues }\end{array}$ & $\begin{array}{l}\text { To describe the Communication } \\
\text { Representation Employing } \\
\text { Systematic Specification (CRESS) } \\
\text { notation and toolset for designing } \\
\text { prompting dialogues that can help } \\
\text { people with mild to moderate } \\
\text { cognitive impairment in their daily } \\
\text { activities }\end{array}$ & $\begin{array}{l}\text { The CRESS notation enabled several } \\
\text { types of dialogues. The dialogues } \\
\text { were automatically carried out on } \\
\text { a VoiceXML platform and were } \\
\text { assessed by volunteers }\end{array}$ & $\begin{array}{l}\text { Testing of } \\
\text { technologies }\end{array}$ \\
\hline Estes and Bloom ${ }^{31}$ & $\begin{array}{l}\text { Using voice recognition } \\
\text { software to treat } \\
\text { dysgraphia in a patient } \\
\text { with conduction aphasia }\end{array}$ & $\begin{array}{l}\text { To describe the use of ATs for } \\
\text { dysgraphia difficulties with patients } \\
\text { suffering from chronic aphasia } \\
\text { with the help of voice recognition } \\
\text { software }\end{array}$ & $\begin{array}{l}\text { Significant improvement in written } \\
\text { skills was attained, but transmission } \\
\text { of these skills for the Internet use } \\
\text { was restricted }\end{array}$ & \\
\hline
\end{tabular}

implanted technology such as cochlear implants. AT devices are identified in IDEA 2004 as:

Any item, piece of equipment or product system, whether acquired commercially off the shelf, modified, or customized, that is used to increase, maintain, or improve the functional capabilities of people with disabilities. ${ }^{11}$

For the purpose of this study, the authors follow the definition provided by Kerr et $\mathrm{al}^{12}$ who see AT as:

Technological devices for personal use designed to enhance the physical, sensory, and cognitive abilities of people with disabilities to help them function more effectively.
However, most of the ATs are designed mainly for people with disabilities although they range from devices such as walkers that help to improve mobility to highly sophisticated devices such as sensor technology. ${ }^{13}$ Figure 2 describes the different types of ATs.

ATs can help people with dementia to improve and prolong the quality of life and make the care provided by their family members, the so-called informal caregivers, easier since people are not able to carry out their daily tasks as the illness progresses. These ATs can delay the need for institutional care. ${ }^{14}$ Thus, ATs can bring the following advantages for these affected people and their caregivers: $:^{15,16}$ 


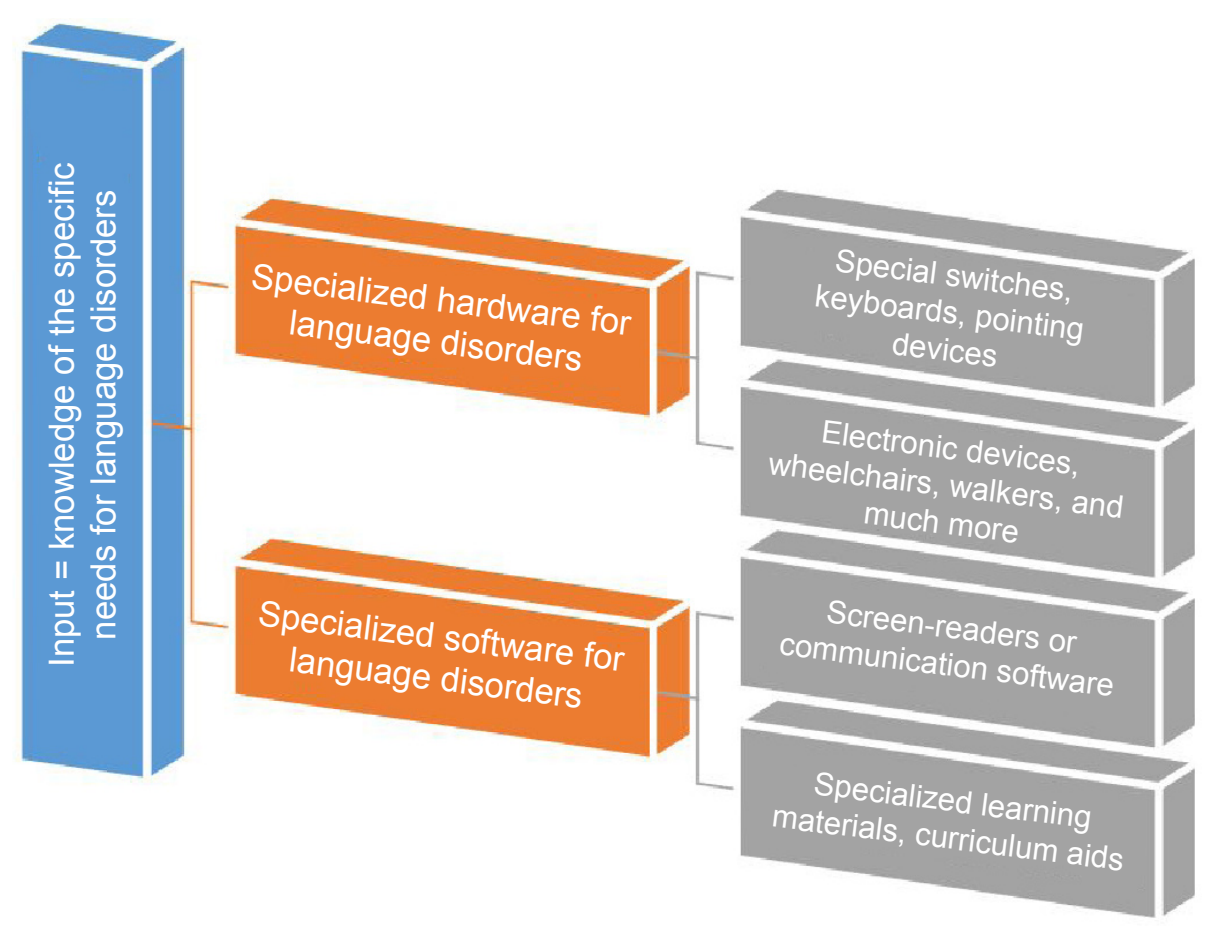

Figure 2 Assistive technologies and their types (authors' own preparation).

- promote independence and autonomy, both for persons with dementia and for those around them ${ }^{17}$

- help manage potential risks in and around the home

- postpone early entry into care homes and hospitals

- facilitate memory and recall

- reduce the stress on caregivers, improving their quality of life and that of persons with dementia.

Moreover, incorporating ATs into treatment of people with dementia can also significantly contribute to reducing costs on placing these people in nursing homes. ${ }^{18,19}$

Table 2 describes the benefits of the selected types of technologies, and their economic aspects according to the available data and benefits according to their division - into hardware and software - are presented in Figure 2.

Costs of ATs are not very high in many cases. In the case of software, a number of freely accessible applications can be used. The hardware components adjusted to the patient's needs correspond to common prices of technologies in a given area. The key problem with the costs is in the area of equipment supporting an overall mobility and independence of a patient. The availability and the benefits of technologies for managing language impairments are good.

However, there are a very small number of ATs now for patients with dementia who suffer from severe cognitive disorders, including language disorders..$^{20,21}$ As Bharucha et $\mathrm{al}^{22}$ claim, the literature on assistive devices for dementia predominantly focuses on the devices for physical disabilities or just on the engineering and computer science domains, and not really on cognitive or functional disorders. In their review study, they found out that ATs for cognitive impairments focused mainly on the development of memory aids.

ATs focusing on cognitive disorders can be divided into two types: ATs for cognition and for augmentative and alternative communication (AAC). According to LoPresti et al, ${ }^{23}$ ATs for cognition disorders are usually sophisticated technological devices that aim at enhancing and improving cognitive procedures, for instance, concentration, remembrance, retrieval of information, spatial orientation, scheduling, or administration activities. The examples of ATs for cognition are prospective memory aids (PMAs) and retrospective memory aids (RMAs). PMAs are aimed at increasing the performance of multiple tasks on a daily basis (eg, memory glasses). Particularly, the memory glasses ${ }^{24}$ can help people with dementia, since these kinds of technological devices can enormously contribute to recalling people's names and recognizing them in an easy manner. However, the evidence base for their effectiveness is nowadays quite restricted since clinical testing with impaired elderly people is lacking. ${ }^{22}$ PMAs can also improve a sequence of steps in both single and multiple tasks. An example of such a device is AutoMinder. ${ }^{25}$ RMAs include, for example, Microsoft's SenseCam, which is a portable digital camera and can make photos on its own. It makes a recording of all activities in a sequential order. Moreover, it does not require any special skills or training 
Table 2 Benefits and economic aspects of technologies in support of patients with Alzheimer's disease

\begin{tabular}{|c|c|c|c|}
\hline & Type of technology & Benefits & Economic aspects and availability \\
\hline \multirow[t]{2}{*}{ Hardware } & $\begin{array}{l}\text { Special switches, keyboards, } \\
\text { and pointing devices }\end{array}$ & $\begin{array}{l}\text { They provide higher security and } \\
\text { a better chance of communication; } \\
\text { they can be time-saving for caregivers }\end{array}$ & $\begin{array}{l}\text { They are widely available on the } \\
\text { market. There is an increase in } \\
\text { the types of devices and their } \\
\text { improvement adjusted according } \\
\text { to a given type of disease; there } \\
\text { is a declining trend in prices } \\
\text { corresponding to the development } \\
\text { of modern technologies }\end{array}$ \\
\hline & $\begin{array}{l}\text { Electronic devices, wheelchairs, } \\
\text { walkers, braces, power lifts, pencil } \\
\text { holders, eye-gaze, head trackers }\end{array}$ & $\begin{array}{l}\text { They provide greater mobility and } \\
\text { independence, and better security for } \\
\text { patients. They can help patients to } \\
\text { remember things and their schedules, } \\
\text { or recall names }\end{array}$ & $\begin{array}{l}\text { Because of high prices of many types } \\
\text { of devices (eg, the average cost of an } \\
\text { electric wheelchair is US } \$ 7,000 \text { but can } \\
\text { range from US } \$ 3,000 \text { to US } \$ 30,000 \text { ), } \\
\text { there is a chance of insurance } \\
\text { contribution (the amount of insurance } \\
\text { is dependent on the type and country) }\end{array}$ \\
\hline \multirow[t]{2}{*}{ Software } & $\begin{array}{l}\text { Screen-readers or communication } \\
\text { software }\end{array}$ & $\begin{array}{l}\text { They enable patients to communicate } \\
\text { with their surroundings; some act } \\
\text { as voice generators and improve } \\
\text { patients' quality of life }\end{array}$ & $\begin{array}{l}\text { In many cases, they are freely } \\
\text { available; the price is dependent } \\
\text { on the purchased hardware }{ }^{43}\end{array}$ \\
\hline & Specialized learning materials & $\begin{array}{l}\text { They act as support for the delay } \\
\text { of the development of the disease, } \\
\text { particularly in its early stages }\end{array}$ & $\begin{array}{l}\text { Many are freely available, for a charge } \\
\text { or free of charge; it is necessary to } \\
\text { buy the corresponding hardware; the } \\
\text { price of specialized learning materials } \\
\text { is not a limitation for their use }\end{array}$ \\
\hline
\end{tabular}

on behalf of a patient. Its purpose is to improve the patient's memory. Research studies ${ }^{22,23}$ have already confirmed a certain level of success in respect of cognitive functions in the treatment of AD in its early stages.

Furthermore, AAC refers to any strategy, technique, or tool that enhances, replaces, augments, or supplements an individual's capabilities. ${ }^{26}$ Besides external memory aids such as notebooks, cards, or timers, these include SGDs and computers that act as people's schedules or reminders. SGDs or voice output communication aids are electronic AAC systems used to enhance or substitute speech or writing for people with severe speech impairments. These devices enable patients to verbally communicate their needs. ${ }^{27}$ Therefore, SGDs are important for individuals who cannot express themselves verbally because they enable them to become active participants in communication interactions. ${ }^{28}$ These devices can be used both with mild to moderate impairments and with severe speech impairments. For example, the study by Turner et $\mathrm{al}^{19}$ describes the Communication Representation Employing Systematic Specification (CRESS) notation and toolset for designing prompting dialogues that can help people with mild to moderate cognitive impairment in their daily activities. But there are also devices that can assist people with aphasia: for instance, SentenceShaper that helps to produce structure utterances. ${ }^{29}$ Researchers also try to use ATs for dysgraphia difficulties with patients suffering from chronic aphasia with the help of voice recognition software. ${ }^{30}$

\section{Discussion}

Although age seems to be one of the key negative aspects in using any kind of technology, ${ }^{31}$ research studies ${ }^{32,33}$ confirm that the older generation of people, aged 58-77 years, are nowadays much more digitally aware than they used to be 10 years ago. This is caused not only by acquiring more experience through different kinds of community and nationwide projects aimed at mentally impaired adults, ${ }^{34,35}$ but also by their desire to communicate with their family (eg, grandchildren). In addition, most of these patients have no difficulties in accessing computers. ${ }^{36}$ Furthermore, research studies ${ }^{33,37,38}$ also prove that elderly people seem to have fewer difficulties with the use of technologies but more with cognition (eg, difficulties in remembering steps) which appear to be time-persistent, and independent of experience and practice with technologies.

There are obvious benefits of using technologies, particularly AAC technologies, for managing language disorders in dementia. These technologies, besides acting as patients' reminders and schedules, can assist people in recalling and recognizing names. Moreover, they can significantly improve and substitute their spoken and written communication. 
However, as the findings on the basis of the review studies ${ }^{22,23}$ show, ATs for people with dementia focus on the maintenance of cognitive functions in general, and there are only a few studies ${ }^{17,27,28}$ on language disorders in dementia. Thus, the initiative taken by the Alzheimer's Association Working Group on Technologies, which made a manual for research of ATs and their development for the impaired patients who can still be on their own, can be a good starting point for this research..$^{39}$ More attention should be paid to the development of ATs focused exclusively on language impairments in all phases of dementia with special focus on aphasia. So far, there have been mainly studies concentrating on memory, safety, and communication but not really on assisting patients with their speech production. ${ }^{13}$

Future research should analyze the needs of impaired people as far as ATs are concerned and more clinical testing should be carried out in order to discover the desired positive outcomes. Peterson et $\mathrm{al}^{40}$ also point out the fact that ATs will become more personalized to patient needs and user requirements. Thus, ATs should be designed in an intelligent, context-aware, unobtrusive, and passive way, which means they should be user-friendly and easy to use. In addition, they should be wearable, low-cost, and discreet. Simply put, they should meet user needs. ${ }^{41}$ ATs could then also contribute to the treatment of other diseases such as epilepsy. ${ }^{42}$

\section{Conclusion}

Overall, it seems that ATs are not implemented widely enough in the treatment of language disorders, but there are certain trends toward improvement in this area. It is obvious that present demographic changes of the world's population and an expected increase in the number of elderly people suffering from dementia, and particularly from cognitive disorders including language impairments, call for urgent research and development in this field. Therefore, collaboration of all stakeholders such as public organizations, academic institutions, and pharmaceutical and technological corporations, including patients, is necessary in order to cover economic, social, medical, and technological aspects of this issue.

\section{Acknowledgments}

This work was supported by the project Excellence at the Faculty of Informatics and Management, University of Hradec Kralove, Czech Republic, and Long-Term Development Plan of University Hospital Hradec Kralove.

\section{Disclosure}

The authors report no conflicts of interest in this work.

\section{References}

1. Alzheimer's Association. Alzheimer's disease facts and figures. Alzheimer's and dementia. 2012. Available from: http://www.alz.org/ downloads/Facts_Figures_2012.pdf. Accessed July 5, 2015.

2. World Health Organization [webpage on the Internet]. 2015. Available from: http://www.who.int/mediacentre/factsheets/fs362/en. Accessed May 8, 2015.

3. Whitehouse PJ. Dementia. Philadelphia, PA: F.A. Davis Company; 1993.

4. A brief introduction to disabilities. 2015. Available from: http://trace. wisc.edu/docs/population/populat.htm. Accessed May 8, 2015.

5. American Speech-Language-Hearing Association. Definitions of communication disorders and variations [Relevant paper]. 1993. Available from: http://www.asha.org/policy/RP1993-00208/. Accessed 8 May, 2015.

6. Krapp KM. Language disorders. Encyclopedia of Nursing \& Allied Health. 2002. Available from: http://www.enotes.com/nursing-encyclopedia/language-disorders. Accessed May 8, 2015.

7. Ek U, Norrelgen F, Westerland J, Dahlman A, Hultby E, Fernell E. Teenage outcomes after speech and language impairment at preschool age. Neuropsychiatr Dis Treat. 2012;8:221-227.

8. Klímová B, Marešová P, Vališ M, Hort J, Kuča K. Alzheimer's disease and language impairments: social intervention and medical treatment. Clin Interv Aging. 2015;10:1401-1407.

9. Tang-Wai DF, Graham NL. Assessment of language function in dementia. Geriatr Aging. 2008;11:103-110.

10. Alzheimer's Society. What is frontotemporal aphasia? 2015. Available from: http://www.alzheimers.org.uk/site/scripts/documents_info. php?documentID=167. Accessed July 14, 2015.

11. Assistive Technology Industry Association. What is assistive technology? How is it funded? 2015. Available from: http://www.atia.org/i4a/ pages/index.cfm?pageid=3859. Accessed May 8, 2015.

12. Kerr D, Cunningham C, Martin S. Telecare and Dementia: using telecare effectively in the support of people with dementia Stirling: Dementia Services Development Centre and Joint Improvement Team, Scottich Government. 2010. Available from: http://carerslink.org.uk/ wp-content/uploads/00259-Telecare-and-dementia-Scotland-freedownload.pdf. Accessed May 8, 2015.

13. Armstrong N, Nugent C, Moore G, Finlay D. Using smartphones to address the needs of persons with Alzheimer's disease. Ann Telecommun. 2010;65:485-495.

14. Sixsmith A, Orpwood R, Torrington J. Quality of life technologies for people with dementia. Top Geriatr Rehabil. 2007;23:85-93.

15. Alzheimer's Society. Assistive technology - devices to help with everyday living. 2015. Available from: http://www.alzheimers.org.uk/ site/scripts/documents_info.php?documentID=109. Accessed May 8, 2015.

16. Marešová P, Klímová B. Supporting Technologies for Old People with Dementia: A Review. IFAC - PapersOnLine. 2015;48(4):129-134.

17. Robinson L, Brittain K, Lindsay S, Jackson D, Olivier P. Keeping In Touch Everyday (KITE) project: developing assistive technologies with people with dementia and their carers to promote independence. Int Psychogeriatr. 2009;21(3):494-502.

18. Johnson N, Davis T, Bosanquet N. The epidemic of Alzheimer's disease. How can we manage the costs? Pharmacoeconomics. 2000;18: 215-223.

19. Turner KJ, Gillespie A, McMichael LJ. Rigorous development of prompting dialogues. J Biomed Inform. 2011;44(5):713-727.

20. Mihailidis A, Barbenel JC, Fernie GR. The efficacy of an intelligent orthosis to facilitate handwashing by persons with moderate-to-severe dementia. Neuropsychol Rehabil. 2004;14:135-171.

21. Rowe M, Lane S, Phipps C. CareWatch: a home monitoring system for use in homes of persons with cognitive impairment. Top Geriatr Rehabil. 2007;23:3-8.

22. Bharucha AJ, Anand V, Forlizzi J, et al. Intelligent assistive technology applications to dementia care: current capabilities, limitations, and future challenges. Am J Geriatr Psychiatry. 2009;17(2):88-104. 
23. LoPresti EF, Mihailidis A, Kirsch N. Assistive technology for cognitive rehabilitation: state of the art. Neuropsychol Rehabil. 2004;14: 5-39.

24. DeVaul RW. The Memory Glasses Project. 2007. Available from: http:// www.media.mit.edu/wearables/mithril/memory-glasses.html. Accessed May 8, 2015.

25. Pollack ME, Brown L, Colbry D, et al. Autominder: an intelligent cognitive orthotic system for people with memory impairment. Rob Auton Syst. 2003;44:273-282.

26. Fried-Oken M. Communication supports for persons with dementia. 2010. Available from: http://www.ohsu.edu/xd/research/centersinstitutes/institute-on-development-and-disability/reknew/research/ upload/Communication-Supports-for-Persons-with-Dementia.pdf. Accessed May 8, 2015.

27. Aetna Inc. Clinical Policy Bulletin: Speech generating devices. 2008. Available from: http://www.aetna.com/cpb/medical/data/400_499/0437. html. Accessed May 8, 2015.

28. Blischak DM, Lombardino LJ, Dyson AT. Use of speech-generating devices: in support of natural speech. Augment Altern Commun. 2003; 19(1):29-35.

29. Linebarger MC, Schwartz MF. AAC for hypothesis - testing and treatment of aphasia language production: lessons from a processing prosthesis. Aphasiology. 2005;19:930-942.

30. Estes C, Bloom RL. Using voice recognition software to treat dysgraphia in a patient with conduction aphasia. Aphasiology. 2011; 25(3):366-385.

31. Barnard Y, Bradley MD, Hodgson F, Lloyd AD. Learning to use new technologies by older adults: perceived difficulties, experimentation behaviour and usability. Comput Human Behav. 2013;29: $1715-1724$.

32. Hanson VL. Age and web access: the next generation. In: Proceedings of the 2010 W4A - Technical; Madrid, Spain; 2009:7-15.
33. Sayago S, Sloan D, Blat J. Everyday use of computer-mediated communication tolls and its evolution over time: an ethnographical study with older people. Interact Comput. 2011;23:543-554.

34. Bishop J. Increasing participation in online communities: a framework for human computer interaction. Comput Human Behav. 2009; 23(4):1881-1893.

35. Godfrey M, Johnson O. Digital circles of support: meeting the information needs of older people. Comput Human Behav. 2009;25:633-642.

36. Heart T, Kalderon E. Older adults: are they ready to adopt health-related ICT? Int J Med Inform. 2013;82:e209-e231.

37. Ames MG, Kaye J, Spasojevic M. Making love in the network closet: the benefits and work of family videochat. In: Proceedings of the 2010 ACM Conference on Computer Supported Cooperative Work; Savannah, GA, USA; 2010:145-154.

38. Selwyn N, Gorard S, Furlong J, Madden L. Older adults' use of information and communication technology in everyday life. Ageing Soc. 2003;23(5):561-582.

39. Mahoney DF, Purtilo RB, Webbe FM, et al. In-home monitoring of persons with dementia: ethical guidelines for technology research and development. Alzheimers Dement. 2007;3:217-226.

40. Peterson CB, Prasad NR, Prasad R. The future of assistive technologies for dementia. Gerontechnology. 2012;11(2):195.

41. Meiland FJM. Functional requirements for assistive technology for people with cognitive impairments and dementia. AmI 2011 Workshop, CCIS 277; 2012:146-151. New York: Springer-Verlag Berlin Heidelberg.

42. Cousin E, Baciu M, Pichat C, Kahane P, Le Bas JF. Functional MRI evidence for language plasticity in adult epileptic patients: preliminary results. Neuropsychiatr Dis Treat. 2008;4(1):235-246.

43. List of Computer Screen Readers for Visually Impaired [webpage on the Internet]. 2014. Available from: http://www.disabled-world.com/assistivedevices/computer/screen-readers.php. Accessed July 14, 2015.
Neuropsychiatric Disease and Treatment

\section{Publish your work in this journal}

Neuropsychiatric Disease and Treatment is an international, peerreviewed journal of clinical therapeutics and pharmacology focusing on concise rapid reporting of clinical or pre-clinical studies on a range of neuropsychiatric and neurological disorders. This journal is indexed on PubMed Central, the 'PsycINFO' database and CAS,

\section{Dovepress}

and is the official journal of The International Neuropsychiatric Association (INA). The manuscript management system is completely online and includes a very quick and fair peer-review system, which is all easy to use. Visit http://www.dovepress.com/testimonials.php to read real quotes from published authors. 